Article

\title{
Structural and Biological Investigations for a Series of N-5 Substituted Pyrrolo[3,2-d]pyrimidines as Potential Anti-Cancer Therapeutics
}

\author{
Brian M. Cawrse ${ }^{1}$, Nia'mani M. Robinson ${ }^{1}$, Nina C. Lee ${ }^{2}$, Gerald M. Wilson ${ }^{2}$ and \\ Katherine L. Seley-Radtke ${ }^{1, * \mathbb{D}}$ \\ 1 Department of Chemistry and Biochemistry, University of Maryland, Baltimore County, Baltimore, \\ MD 21250, USA \\ 2 Department of Biochemistry and Molecular Biology, University of Maryland School of Medicine, Baltimore, \\ MD 21201, USA \\ * Correspondence: kseley@umbc.edu; Tel.: +1-410-455-8684
}

Academic Editor: Christian Ducho

Received: 1 July 2019; Accepted: 22 July 2019; Published: 23 July 2019

\begin{abstract}
Pyrrolo[3,2- $d$ ]pyrimidines have been studied for many years as potential lead compounds for the development of antiproliferative agents. Much of the focus has been on modifications to the pyrimidine ring, with enzymatic recognition often modulated by $\mathrm{C} 2$ and $\mathrm{C} 4$ substituents. In contrast, this work focuses on the N5 of the pyrrole ring by means of a series of novel N5-substituted pyrrolo[3,2- $d$ ] pyrimidines. The compounds were screened against the NCI-60 Human Tumor Cell Line panel, and the results were analyzed using the COMPARE algorithm to elucidate potential mechanisms of action. COMPARE analysis returned strong correlation to known DNA alkylators and groove binders, corroborating the hypothesis that these pyrrolo[3,2- $d]$ pyrimidines act as DNA or RNA alkylators. In addition, N5 substitution reduced the $\mathrm{EC}_{50}$ against CCRF-CEM leukemia cells by up to 7-fold, indicating that this position is of interest in the development of antiproliferative lead compounds based on the pyrrolo[3,2-d]pyrimidine scaffold.
\end{abstract}

Keywords: pyrrolo[3,2-d]pyrimidine; anti-cancer; antiproliferative; DNA damage; DNA alkylator

\section{Introduction}

Pyrrolo[3,2- $d]$ pyrimidines, or 9-deazapurines, represent a class of compounds that are sterically and electronically similar to the naturally occurring purine nucleobases, with the exception of a hydrogen-bond donating moiety at N5 (Figure 1) [1-3]. These compounds have seen widespread biological activity and have been extensively utilized in the design of small molecule inhibitors of purine nucleoside phosphorylase (PNP) [4-9], dihydrofolate reductase (DHFR) [3], the transient receptor potential channel family [10], and various kinases [11-13]. In addition, pyrrolo[3,2-d]pyrimidines have shown promise in the development of antitumor agents [1,14-16]. The research detailed herein examined the effect of N5 substitution on the pyrrolo[3,2-d]pyrimidine scaffold, with ten novel compounds synthesized and subsequently tested for antiproliferative activity.
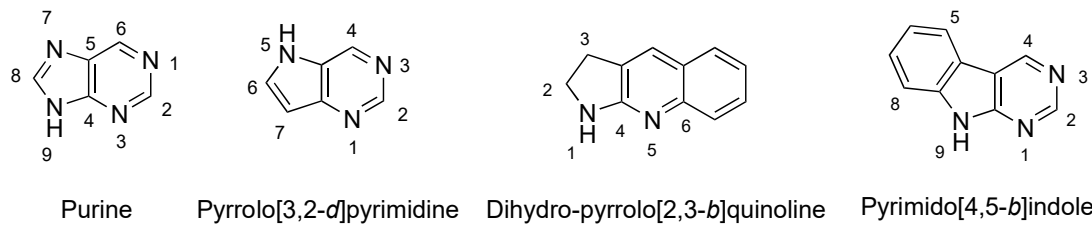

Pyrrolo[3,2-d]pyrimidine Dihydro-pyrrolo[2,3-b]quinoline

Pyrimido[4,5-b]indole

Figure 1. Structures of biologically relevant heterocycles. 
N5 and C7 substitutions have been shown by multiple researchers to play important roles in the potency of pyrrolo[3,2-d]pyrimidines designed as enzyme inhibitors and potential therapeutics. Recently, the pyrrolo[3,2- $d$ ]pyrimidine scaffold has been shown to inhibit Multi-drug Resistance-Associated Protein 1 (MRP1), an active efflux transporter responsible for resistance to a wide variety of antiproliferative agents $[1,17]$. Similarly, multiple quinazolinone scaffolds have been investigated as potent inhibitors of MRP1 [18,19], which led to the development of dihydropyrroloquinoline [20], indolopyrimidine [21], and pyrrolopyrimidine $[1,17,18,21]$ inhibitors (Figure 1).

Schmitt et al. synthesized a large series of 7-cyano-pyrrolo[3,2- $d]$ pyrimidines that mapped the effects of various substituents at C4, N5, and C6 [1,17,22]. Their findings suggested that an aliphatic group at N5 increased activity against MRP1, but this activity was not further increased by the addition of aromatic rings at the end of the aliphatic N5 chains (Figure 2A) [22]. A second study by the same group verified the increase in MRP1 activity with N5 aliphatic substitutions, with a cyclopropyl group imparting the greatest effect (Figure 2B) [17].

A

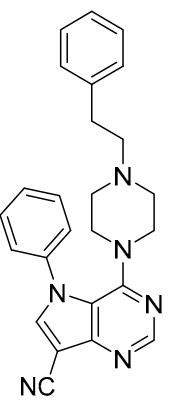

B

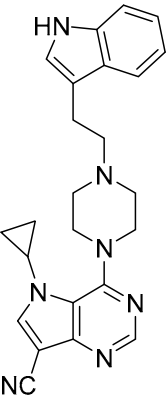

C

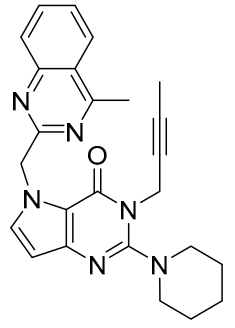

D<smiles>N#Cc1ccccc1Cn1c(N2CCCCC2)nc2c(Br)c[nH]c2c1=O</smiles>

E

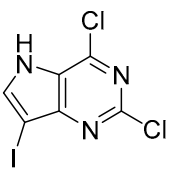

Figure 2. Structures of active pyrrolo[3,2- $d$ ]pyrimidines. (A and B) Inhibitors of multidrug resistance protein 1 (MRP1), P-glycoprotein, and breast cancer resistance protein (BCRP). (C and D) Inhibitors of dipeptidyl peptidase IV (DPP-IV). (E) Broad-spectrum antiproliferative agent, with potent activity against MIA PaCa-2 pancreatic cells.

Zeng et al. synthesized C2/N3 substituted pyrrolo[3,2- $d$ ]pyrimidine inhibitors of dipeptidyl peptidase IV (DPP-IV) that explored the effect of various quinolone and quinazoline substituents, finding that different N5 bicyclic substituents had widely differential activities (1.5-139 nM, Figure 2C) [23]. Related to this, Xie et al. synthesized N2/N3 substituted pyrrolo[3,2- $d$ ]pyrimidines as potent and selective inhibitors of dipeptidyl peptidase IV (DPP-IV) that explored the effect of C7 substitution, finding that C7-bromine imparted the greatest desired activity (Figure 2D) [24].

Finally, Temburnikar et al. previously determined that 2,4-dichloro-pyrrolo[3,2- $d$ ]pyrimidines showed broad-spectrum antiproliferative activity, which was greatly enhanced via $\mathrm{C} 7$ halogenation (Figure 2E) $[16,25,26]$. In addition, N5 substitution led to a marked decrease in toxicity, lending credence to the hypothesis that the toxicity of these halogenated pyrrolo[3,2- $d]$ pyrimidines can be modulated in order to take full advantage of their potent antiproliferative properties [15].

These studies all suggested that the N5 position of pyrrolo[3,2- $d]$ pyrimidines was of interest in potentially improving activity and modulating toxicity. As a result, a series of N5 substituted compounds were synthesized and characterized as part of an ongoing structure-activity relationship study, designed to investigate the effect of various substituents at N5. The target compounds are shown in Figure 3. The sulfonamide compounds $\mathbf{6 - 8}$ are a continuation of a previous study that indicated that N5 sulfonamide substituents decreased toxicity without adversely affecting activity [15]. The benzyl compound series 9-11 provided an opportunity to explore whether the N5 substituent requires hydrolytic cleavage prior to antiproliferative activity, as was indicated in earlier pharmacokinetic testing [15]. Amide substitution products 12-14 represent a series of compounds possessing the 
naturally occurring and medicinally prevalent amide group. Finally, the addition of a polar aliphatic alcohol decreased $\log P$ from 1.66 for parent compound 5 to 1.38 for compound 15 , allowing investigation of the effects of increased aqueous solubility.

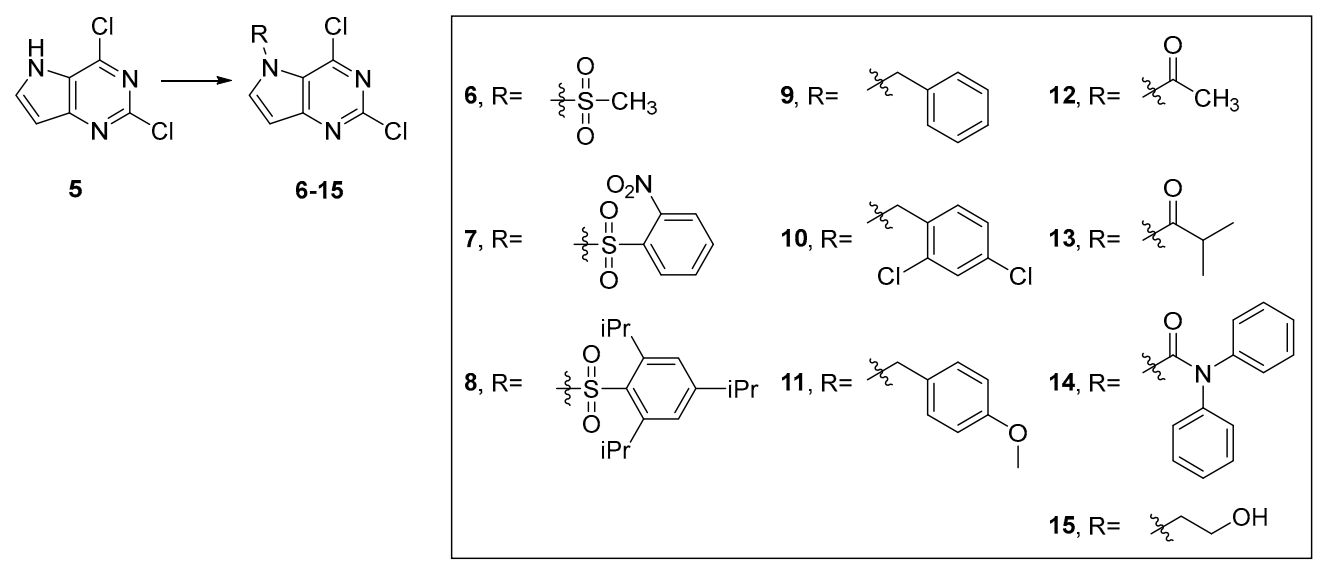

Figure 3. Target compounds, starting from parent compound 5. Compounds 6-15 were submitted to the National Cancer Institute for NCI-60 cell line screening.

The most active compounds from the NCI-60 cell line screen $(7,9,10$, and 14) were subjected to cell assays to determine their activity against the cell line CCRF-CEM, an acute lymphoblastic leukemia cell line, derived from $\mathrm{T}$ lymphoblast cells [27]. Finally, chemical and pharmacokinetic properties were calculated using Schrodinger QikProp software (Schrodinger, LLC., New York, NY, USA) [28].

\section{Results}

\subsection{National Cancer Institute-60 Human Tumor Cell Line Screen and COMPARE Analysis}

In 1990, the National Cancer Institute (NCI) established a 60 human cell line screen for the evaluation of antiproliferative agents [29-31]. Represented cell lines encompass leukemia, melanoma, lung, colon, nervous system, ovarian, renal, prostate, and breast cancers. Compounds 6-15 were screened at $10 \mu \mathrm{M}$ concentrations, and the results indicated that N5 substitution has a significant effect on both activity and selectivity. The results are presented in terms of growth percent (GP), which is the growth of a treated culture compared to the growth of an untreated culture, i.e., $60 \%$ GP represents $40 \%$ growth inhibition, compared to a negative control cell culture [30]. GP between 0-99 represents cytostatic properties; between $-100-0$ represents cytotoxic properties [30]. Table 1 shows the best growth percent for each compound, which represents the maximal inhibitory effect against the most affected cell line. The complete NCI-60 data can be found in the Supplemental Information.

Overall, the compounds were minimally active as broad-spectrum antiproliferatives, but did have specificity leukemia cell lines, with good activity for compounds 7, 9, 10, and $\mathbf{1 4}$. Compound 7 affected the cell growth in leukemia (CCRF-CEM, K-562, and RPMI-8226) cell lines, with an average GP of $63.6 \%$ (Supplemental Information). Compound 7 showed best growth inhibition against NCI-H522 non-small cell lung cancer (49.5\% GP) but did not affect other non-small cell lung cancer lines. The two other sulfonyl substituted compounds ( 6 and 8$)$ did not show significant activity. Benzyl substituted compounds 9-11 showed the best activity against the CCRF-CEM leukemia cell line, with GP ranging from 22.88-65.83 (Table 1). Compound 10 also displayed potent activity against NCI-H522 non-small cell lung cancer, with a 35.1\% GP (Supplemental Information). Within the amide substituted compounds 12-14, only 14 showed appreciable activity, and in general, this compound was the most potent. Notably, this compound was the only one to show lethality against breast cancer cell lines, with $-0.95 \%$ GP against MDA-MB-468 (Table 1). Finally, hydroxyethyl substituted 15 showed decreased activity compared to parent 5 . 
Table 1. Best Growth Percent and Target Cell Line for Compounds 5-15.

\begin{tabular}{ccc}
\hline Compound & Best Growth Percent $^{*}$ & Most Affected Cell Line \\
\hline $\mathbf{5}$ & 60.77 & LOX-IMVI (Melanoma) \\
$\mathbf{6}$ & 84.49 & NCI-H522; NSC Lung \\
$\mathbf{7}$ & 49.57 & NCI-H522; NSC Lung \\
$\mathbf{8}$ & 93.16 & UO-31; Renal \\
$\mathbf{9}$ & 36.31 & CCRF-CEM; Leukemia \\
$\mathbf{1 0}$ & 22.88 & CCRF-CEM; Leukemia \\
$\mathbf{1 1}$ & 65.83 & CCRF-CEM; Leukemia \\
$\mathbf{1 2}$ & 81.36 & UO-31; Renal \\
$\mathbf{1 3}$ & 75.18 & SR, Leukemia \\
$\mathbf{1 4}$ & -0.95 & MDA-MB-468; Breast \\
$\mathbf{1 5}$ & 89.73 & NCI-H522; NSC Lung \\
\hline
\end{tabular}

* Represents the growth percent in the most affected cell line (i.e., highest antiproliferative activity exhibited in the NCI-60 cell screening).

COMPARE analysis [31-36] was then performed for compounds 5-15 against the NCI Standard Agents list, an aggregate of 171 compounds that have shown clinical antiproliferative activity. The analysis returns a Pearson correlation coefficient (PCC; $[37,38]$ ) that ranges from -1.0 to 1.0 , representing the statistical similarity of a compound, compared to the activity of the known standard with 1.0 representing a perfect match, and -1.0 representing a perfect mirror image of the compared activities [31]. Moderate correlation is represented by PCC values between $0.5-0.7$, and strongly analogous compounds generally have a PCC of $\geq 0.7$ [39]. The top five correlation results all had PCC $\geq 0.6$, indicating a moderate correlation (Table 2 ).

Table 2. Pearson Correlation Coefficient of Selected Compounds with Target Vector and Common Cell Line Count.

\begin{tabular}{cccc}
\hline Compound & Correlation (PCC) & Target Vector ${ }^{\text {a }}$ & Common Cell Line Count $^{\mathbf{b}}$ \\
\hline $\mathbf{9}$ & 0.717 & D-Tetrandrine & 55 \\
$\mathbf{7}$ & 0.661 & Pibenzimol HCl & 57 \\
$\mathbf{9}$ & 0.640 & Fluorodopan & 58 \\
$\mathbf{9}$ & 0.622 & Melphalan & 58 \\
$\mathbf{9}$ & 0.622 & Carmustine (BCNU) & 59 \\
\hline
\end{tabular}

${ }^{a}$ Known compound with activity most comparable to experimental compound; ${ }^{b}$ Number of cell lines displaying similar activity between experimental compound and target vector.

\subsection{In Vitro Cell Growth Inhibition}

Based on the results of the NCI-60 screen, compounds 7, 9, 10, and 14 were selected for in vitro assays against CCRF-CEM leukemia cells, using a commercially available MTT assay kit [27]. The most active compound in this assay was 10 , with an $\mathrm{EC}_{50}=3.3 \pm 1.2 \mu \mathrm{M}$; the least active compound was 9, with $\mathrm{EC}_{50}=23.2 \pm 2.0 \mu \mathrm{M}$. The single digit micromolar $\mathrm{EC}_{50}$ values observed for 7, 10, and $\mathbf{1 4}$ represent an approximately 7 -fold increase in activity compared to parent unsubstituted compound $\mathbf{5}$, which has low activity against CCRF-CEM cells $\left(\mathrm{EC}_{50}{ }^{\text {CCRF-CEM }}=25 \pm 2 \mu \mathrm{M}\right)$ [16]. The results of the contemporary assays are shown in Figure 4. 

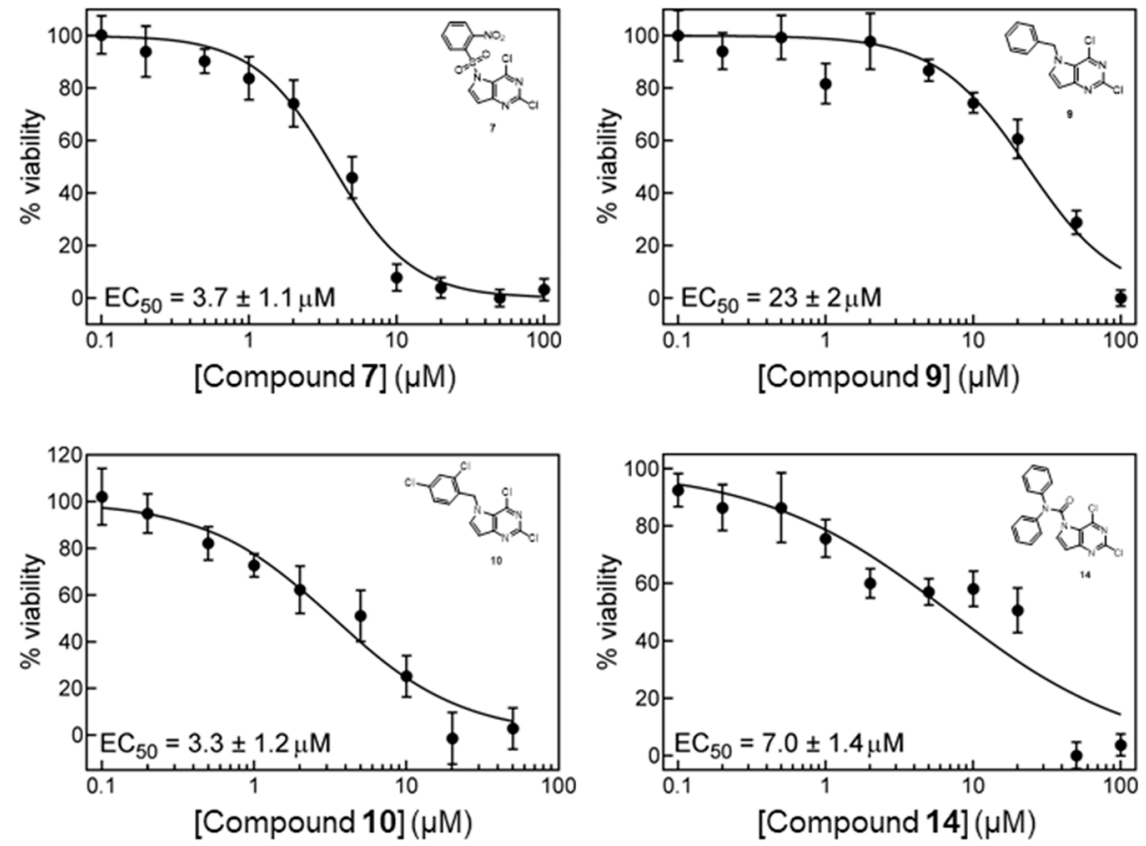

Figure 4. CCRF-CEM MTT assay results.

\section{Discussion}

Previous studies on pyrrolo[3,2- $d]$ pyrimidines indicate that the scaffold holds promise in the development of potent antiproliferative agents [16]. Halogenated pyrrolo[3,2- $d$ ]pyrimidines, synthesized previously by the Seley-Radtke laboratory, exhibited low micromolar to nanomolar activity against a wide variety of cancer cell lines, with results indicating that N5 substitution allows modulation of toxicity and activity $[15,16]$. The SAR study presented here corroborated those results, with NCI-60 cell line screening showing good activity and specificity against CCRF-CEM leukemia.

The results observed for compounds 9-11 strongly suggest that enzymatic cleavage of the N5 substituent is not required for biological activity, as the benzyl substituents are assumed to be stable under physiological conditions. Interestingly, this series showed the best activity as a group, with preferential inhibition in leukemia cultures. Leukemia cells have been associated with an abnormally high rate of cell proliferation (cell birth rates have been measured at $0.07-1.31 \%$ per day), as well as a low rate of cell death $[40,41]$. In addition, acute myeloid leukemia has been demonstrated to have an increased expression of non-coding RNA (miRNA), associated with leukemia pathogenesis and leukemogenesis, providing additional nucleic acid targets for DNA/RNA alkylating molecules [42,43]. This correlates with the trend for preferential leukemia growth inhibition observed for 9-11.

The necessity for aromatic substituents was further demonstrated in the acyl/amide substituted compounds 12-14, with the acetyl- and isobutyryl-substituted compounds 12 and $\mathbf{1 3}$ showing little growth inhibition, compared to the significant inhibitory activity of $N, N$-diphenylcarboxamide 14 . Compound $\mathbf{1 4}$ showed the greatest inhibitory activity overall, suggesting that the single aromatic ring present in 7-11 may not be sufficient to impart maximal inhibitory activity.

Hydroxyethyl substituted 15 showed the least inhibitory action of all of the compounds tested, suggesting that increased hydrophilicity is not a factor in the activity of these compounds.

COMPARE analysis returned moderate to strong correlation to d-tetrandrine, pibenzimol hydrochloride, fluorodopan, melphalan, and carmustine. D-tetrandrine is a naturally occurring benzylisoquinoline alkaloid that has been shown to associate with DNA and RNA in sarcoma cell lines [44]; pibenzimol HCl is a benzimidazole DNA minor groove binder and inhibitor of topoisomerase I [45,46]; fluorodopan is a halogenated pyrimidine-2,4-dione once considered as a possible treatment for colorectal cancer [47]; melphalan and carmustine are both alkylating nitrogen mustards used to treat multiple myeloma, and glioblastoma, respectively [48,49]. These compounds all share a similar 
mechanism of action-direct association or alkylation of nucleic acids, suggesting that compounds 6-15 may follow a similar mechanism. This observation supports previous studies that indicated the compounds operate via an alkylation mechanism. Briefly, flow cytometry revealed an accumulation in the G2/M phase, consistent with a DNA damage checkpoint, and $\gamma-\mathrm{H} 2 \mathrm{Ax}$ staining of cell cultures treated with an analogue of parent 5 revealed DNA damage $[15,16]$. In addition, a proteomic study did not reveal any covalent protein targets, which suggested that the inhibition of enzymes such as topoisomerases is unlikely (unpublished results).

The in vitro cell proliferation assays showed that compound $\mathbf{1 0}$ was the most efficacious at preventing cell proliferation, with an $\mathrm{EC}_{50}=3.3 \pm 1.2 \mu \mathrm{M}$. Compound 9 was the least effective, with an $\mathrm{EC}_{50}=23 \pm 2 \mu \mathrm{M}$. The low $\mathrm{EC}_{50}$ observed for compound 9 may be due to the chemical properties of this compound, in particular the solvent accessible surface area (SASA) and electron affinity (EA). Of the four compounds tested, 9 has the lowest SASA and EA, which would hinder the bioavailability and ability to accept an electron during an alkylation reaction, (Table 3) [50]. However, compared to the parent compound 5 (2,4-dichloro-5H-pyrrolo[3,2- $d$ ]pyrimidine), compounds 7, 10, and 14 all showed better activity in CCRF-CEM cells by up to a factor of $\sim 7\left(\right.$ EC $_{50}$ CCRF-CEM $=25 \pm 2 \mu \mathrm{M}$ for compound 5) [16], indicating that N5 substitution may offer a viable path for development of potent antiproliferative lead compounds.

Table 3. Physical and pharmacokinetic properties of active pyrrolo[3,2- $d]$ pyrimidines.

\begin{tabular}{ccccc}
\hline Compound & SASA $^{\mathbf{a}}{\left(\AA^{2}\right)}^{\mathbf{2}}$ & $\mathbf{E A}^{\mathbf{b}}(\mathbf{e V})$ & QPPCaco $^{\mathbf{c}}(\mathbf{n m} / \mathbf{s e c})$ & QPlogS $^{\mathbf{d}}\left(\boldsymbol{l o g}\left[\mathbf{m o l} / \mathbf{d m}^{3}\right]\right)$ \\
\hline $\mathbf{7}$ & 514.262 & 9.613 & 243.855 & -2.017 \\
$\mathbf{9}$ & 476.642 & 8.878 & 3989.857 & -4.405 \\
$\mathbf{1 0}$ & 509.662 & 8.947 & 4018.835 & -5.547 \\
$\mathbf{1 4}$ & 601.2 & 9.071 & 1349.875 & -4.892 \\
\hline
\end{tabular}

\footnotetext{
${ }^{\mathrm{a}}$ solvent accessible surface area; ${ }^{\mathrm{b}}$ electron affinity; ${ }^{\mathrm{c}}$ predicted apparent Caco- 2 cell permeability; ${ }^{\mathrm{d}}$ predicted
} aqueous solubility.

In summary, the structure-activity relationship study of compounds 6-15 revealed that aromatic substitutions impart increased activity, with a trend towards inhibition of leukemia. The addition of a small polar substituent (compound 15) resulted in activity similar to that of the parent compound 5, suggesting that hydrophilicity does not affect activity. These compounds do not appear to have a particular protein target, and instead mirror the activity of known DNA alkylators and groove binders. This is in line with earlier findings of DNA damage by analogues of parent compound 5. In vitro assays show low micromolar $\mathrm{EC}_{50}$ values for three of the four most active compounds, which represents a 7-fold increase in activity, compared to the unsubstituted parent compound. Together, these data support that halogenated pyrrolo[3,2- $d$ ]pyrimidines act as non-specific antiproliferative agents with tunable activity via N5 substitution, and that further study of N5 substituents holds the potential to improve activity and cell line specificity.

\section{Materials and Methods}

\subsection{NCI-60 Human Tumor Cell Lines Screen and COMPARE Analysis}

The standard operating procedures for the NCI-60 cell line screen have been well-documented and reported in multiple sources [29,30,33,36]. Briefly, accepted antiproliferative compounds are dissolved in DMSO, then stored frozen prior to use. All cultures are grown in RPMI 1640 medium, supplemented with $5 \%$ bovine serum albumin and $2 \mathrm{mM}$ L-glutamine. Prior to evaluation, cultures are dispensed into 96-well microtiter plates at densities between 5000-40,000 cells/well, then incubated for $24 \mathrm{~h}$ at $37^{\circ} \mathrm{C}, 5 \%$ $\mathrm{CO}_{2}, 95 \%$ air, $100 \%$ humidity. Time zero cell density is determined by fixing two wells with trichloroacetic acid (TCA). Experimental compounds are diluted to $10 \mu \mathrm{M}$ in complete medium containing $50 \mu \mathrm{g} / \mathrm{mL}$ gentamicin and administered to plate wells. Plates are incubated for $48 \mathrm{~h}$, followed by addition of TCA to a final concentration of $10 \%$ and held at $60{ }^{\circ} \mathrm{C}$ for $4 \mathrm{~h}$. Supernatant is discarded, and protein content 
of wells is determined by sulforhodamine B staining. Percentage growth inhibition is determined relative to DMSO-treated cells and time-zero control wells. A list of current cell lines included in the NCI-60 screen can be found at https://dtp.cancer.gov/discovery_development/nci-60/cell_list.htm, and is also detailed in the NCI-60 data in the Supplementary Information.

COMPARE analysis was performed using the publicly available online COMPARE algorithm [51]. Using compounds 6-15 as seed compounds, and by comparing to the NCI Standard Agents list, growth inhibition patterns can be compared across the NCI-60 screening results. The results were quantitated as a Pearson correlation coefficient (PCC) with high-ranking compounds, suggesting a mechanism of action similar to that of the seed compounds [33]. Parameters selected for analysis were: Target Set Name: Standard Agents; Target Set Endpoint: $\mathrm{GI}_{50}$; Minimum Correlation: 0.4; Minimum Count Common Cell Lines: 40; Minimum Standard Deviation: 0.05.

\subsection{In Vitro Cell Growth Inhibition}

A total of $4 \mathrm{mM}$ stock solutions of compounds $7, \mathbf{9}, \mathbf{1 0}$, and 14 were prepared in DMSO to be used in serial dilutions to achieve final concentrations of $0,0.1,0.2,0.5,1,2,5,10,20,50$, and $100 \mu \mathrm{M}$ in cell-seeded 96-well plates. Human lymphocytic CCRF-CEM cells were obtained from the American Type Culture Collection (ATCC, Rockville, MD, USA) and cultured in RPMI 1640 (Corning Life Sciences, Tewksbury, MA, USA) containing $1 \times$ penicillin/streptomycin (Corning) and $10 \%$ fetal calf serum (Sigma-Aldrich, St. Louis, $\mathrm{MO}, \mathrm{USA}$ ) at $37^{\circ} \mathrm{C}$ in a humidified, $\mathrm{CO}_{2}$-controlled incubator. The cytostatic assays were performed by incubating $5 \times 10^{4}$ CCRF-CEM cells in $0.1 \mathrm{~mL}$ media with the described concentration of test compounds or vehicle (DMSO) for $48 \mathrm{~h}$. Cell viability was then measured using the MTT Cell Proliferation Assay kit (ATCC) according to the manufacturer's instructions, with absorbance measured at $595 \mathrm{~nm}$. Percent cell viability was calculated relative to cells incubated with vehicle alone, then plotted as a function of drug concentration. $\mathrm{EC}_{50}$ values were resolved by analyzing viability curves using a 4-parameter dose response function utilizing PRISM v3.03 software (GraphPad, San Diego, CA, USA).

\subsection{Chemistry}

\subsubsection{General Experimental}

All solvents and reagents purchased through Fisher Scientific (Hampton, NH, USA) or Sigma-Aldrich (St. Louis, MO, USA). All ${ }^{1} \mathrm{H}$ - and ${ }^{13} \mathrm{C}-\mathrm{NMR}$ were obtained on a JEOL ECX $400 \mathrm{MHz}$ NMR. All NMR spectra were referenced to tetramethylsilane (TMS) at $0.0 \mathrm{ppm}$. The spin multiplicities are indicated by the symbols $\mathrm{s}$ (singlet), $\mathrm{d}$ (doublet), dd (doublet of doublets), $\mathrm{t}$ (triplet), q (quartet), $\mathrm{m}$ (multiplet), and br (broad). All NMR solvents were obtained from Cambridge Isotope Laboratories. All reactions were monitored by thin-layer chromatography (TLC) on $0.25 \mathrm{~mm}$ precoated silica glass plates. All column chromatography was run 32-63 micron silica gel obtain from Dynamic Adsorptions Inc. (Norcross, GA, USA). Yields refer to chromatographically and spectroscopically homogenous materials. All mass spectra were recorded and obtained from the UMBC Mass Spectrometry Facility using a Bruker amazon Speed Ion Trap fitted with an electrospray (ESI) or atmospheric pressure chemical ionization (APCI) injection port. Elemental analysis was conducted by Atlantic Microlabs (Norcross, GA, USA) via combustion analysis.

\subsubsection{Synthesis of Target Compound 5}

Parent compound 5 was synthesized starting from commercially available 6-methyluracil (1), shown in Scheme 1. Nitration at C5 was accomplished by adding 6-methyluracil to a solution of concentrated sulfuric and nitric acids at $0{ }^{\circ} \mathrm{C}$, followed by quenching in ice water to give 2 as a pale yellow solid [24]. This was followed by a modified Batcho-Leimgruber indole synthesis to first prepare enamine 3 [52,53]. Ring cyclization is accomplished by reduction of the nitro moiety to an amino group, with subsequent nucleophilic attack at $\mathrm{C} 8$ by the amino lone pair with loss of 
dimethylamine. The reduction of the nitro group is accomplished by stirring 3 in acetic acid and zinc dust overnight at $80^{\circ} \mathrm{C}$, followed by filtration, formation of the $\mathrm{N} 5$ sodium salt via $\mathrm{NaOH}$ dissolution, then re-acidification and collection of solid 4 [23,54].

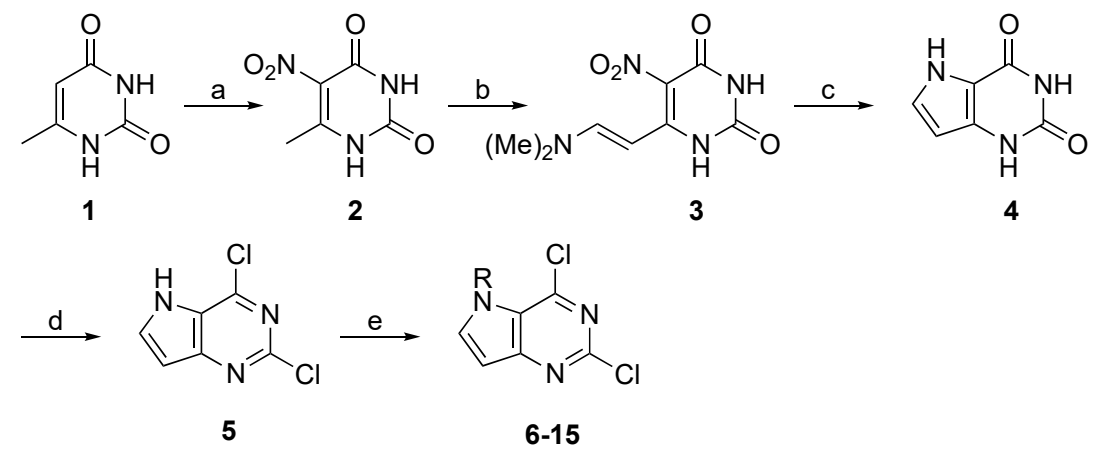

Reagents and Conditions: a) $\mathrm{H}_{2} \mathrm{SO}_{4}, \mathrm{HNO}_{3}$, rt, 2h, 80\%; b) DMF-DMA, DMF, 80 to 140 ${ }^{\circ} \mathrm{C}, 1 \mathrm{~h}, 70 \%$; c) $\mathrm{AcOH}, \mathrm{Zn}$ (dust), rt, $12 \mathrm{~h}, 70 \%$; d) $\mathrm{PhPOCl}_{2}$, reflux, $6 \mathrm{~h}, 60 \%$; e) DMF:THF 1:1, NaH, R-X, rt, $16 \mathrm{~h}, 60-80 \%$

Scheme 1. Synthesis of parent 2,4-dichloro-pyrrolo[3,2- $d]$ pyrimidine 5 and N5 substituted analogues 6-15.

The parent compound 5 was synthesized by first reforming the sodium salt of 4 , by stirring compound 4 in $1 \mathrm{M} \mathrm{NaOH}$ at $40{ }^{\circ} \mathrm{C}$ for one hour, then followed by crystallization at $0{ }^{\circ} \mathrm{C}$ and repeated washes with cold water and acetone. Chlorination of the sodium salt of 4 was achieved by refluxing for $5 \mathrm{~h}$ in phenylphosphonic dichloride under a nitrogen atmosphere. Substitution at N5 was accomplished by N5 deprotonation using sodium hydride at $0{ }^{\circ} \mathrm{C}$, followed by addition of the appropriate halogenated reagent to obtain target compounds 6-15.

\subsubsection{General Procedure for Synthesis of Compounds 6-15}

2,4-dichloro-1H-pyrrolo[3,2-d]pyridine (5) was dissolved in a solution of 1:1 THF:DMF under $\mathrm{N}_{2}$. Sodium hydride (60\% suspension in oil) was added directly, and the mixture was stirred at room temperature for $1 \mathrm{~h}$. Appropriate halogenated reagent (methanesulfonyl chloride (6), 2-nitrobenzenesulfonyl chloride (7), 2,4,6-Triisopropylbenzenesulfonyl chloride (8), benzyl bromide (9), 2,4-dichlorobenzyl bromide (10), 4-methoxybenzyl chloride (11), acetyl chloride (12), isobutyryl chloride (13), diphenylcarbamyl chloride (14), iodoethane (15)) was added and the mixture was stirred at r.t. for $18 \mathrm{~h}$. The solvent was removed and residue dissolved in EtOAc and washed with water and brine, then dried over $\mathrm{MgSO}_{4}$. Organics were loaded onto Celite and product purified using silica column chromatography eluting with 4:1 hexanes:EtOAc or 9:1 DCM:MeOH to obtain product, generally as a white to off-white solid.

\subsubsection{Characterization}

2,4-dichloro-5-(methylsulfonyl)-5H-pyrrolo[3,2-d]pyrimidine (6). ${ }^{1} \mathrm{H}-\mathrm{NMR}\left(400 \mathrm{MHz}, \mathrm{CDCl}_{3}\right)$ (ppm) $\delta: 3.66$ $(\mathrm{s}, 3 \mathrm{H}) ; 6.83(\mathrm{~d}, J=4.12 \mathrm{~Hz}, 1 \mathrm{H}) ; 8.10(\mathrm{~d}, J=4.12 \mathrm{~Hz}, 1 \mathrm{H}) .{ }^{13} \mathrm{C}-\mathrm{NMR}\left(100 \mathrm{MHz}, \mathrm{DMSO}-d_{6}\right): \delta 158.79$, $153.40,152.14,144.44,139.10,137.58,124.23,123.05,105.97,102.31,44.88$. ESI-MS $m / z$ for $\mathrm{C}_{7} \mathrm{H}_{5} \mathrm{Cl}_{2} \mathrm{~N}_{3} \mathrm{O}_{2} \mathrm{~S}$ calcd. at 264.95, found at 266.01 [M+ H] $]^{+}$. Anal. calcd. for $\mathrm{C}_{7} \mathrm{H}_{5} \mathrm{Cl}_{2} \mathrm{~N}_{3} \mathrm{O}_{2} \mathrm{~S}$ : C, 31.60; $\mathrm{H}, 1.89 ; \mathrm{N}, 15.79$. Found: C, 31.58; H, 1.89; N, 15.78 .

2,4-dichloro-5-((2-nitrophenyl)sulfonyl)-5H-pyrrolo[3,2-d]pyrimidine (7). ${ }^{1} \mathrm{H}-\mathrm{NMR}\left(400 \mathrm{MHz}, \mathrm{DMSO}-d_{6}\right)$ (ppm) $\delta: 7.20(\mathrm{t}, J=2.32 \mathrm{~Hz}, 1 \mathrm{H}) ; 7.75(\mathrm{~d}, J=8.24 \mathrm{~Hz}, 1 \mathrm{H}) ; 7.82(\mathrm{t}, J=7.80 \mathrm{~Hz}, 1 \mathrm{H}) ; 8.04(\mathrm{q}, J=7.32$ $\mathrm{Hz}, 1 \mathrm{H}) ; 8.25(\mathrm{~d}, J=7.80 \mathrm{~Hz}, 1 \mathrm{H}) ; 8.60(\mathrm{~d}, J=2.76 \mathrm{~Hz}, 1 \mathrm{H}) .{ }^{13} \mathrm{C}-\mathrm{NMR}\left(100 \mathrm{MHz}, \mathrm{DMSO}-d_{6}\right): \delta 158.30$, $152.97,147.51,144.41,140.13,137.28,134.88,131.37,130.61,126.68,108.04,102.79$. ESI-MS $m / z$ for $\mathrm{C}_{12} \mathrm{H}_{6} \mathrm{Cl}_{2} \mathrm{~N}_{4} \mathrm{O}_{4} \mathrm{~S}$ calcd. at 371.95, found at $373.00[\mathrm{M}+\mathrm{H}]^{+}$. Anal. calcd. for $\mathrm{C}_{12} \mathrm{H}_{6} \mathrm{Cl}_{2} \mathrm{~N}_{4} \mathrm{O}_{4} \mathrm{~S}$ : C, 38.62; H, 1.62; N, 15.01. Found: C, 38.61; H, 1.62; N, 15.01. 
2,4-dichloro-5-((2,4,6-triisopropylphenyl)sulfonyl)-5H-pyrrolo[3,2-d]pyrimidine (8). ${ }^{1} \mathrm{H}-\mathrm{NMR}(400 \mathrm{MHz}$, $\left.\mathrm{CDCl}_{3}\right)(\mathrm{ppm}) \delta: 1.08(\mathrm{~d}, J=6.84 \mathrm{~Hz}, 12 \mathrm{H}) ; 1.24(\mathrm{~d}, J=6.88 \mathrm{~Hz}, 6 \mathrm{H}) ; 2.92$ (septet, $\left.1 \mathrm{H}\right) ; 3.85$ (septet, $\left.2 \mathrm{H}\right)$; $6.83(\mathrm{~d}, J=3.64 \mathrm{~Hz}, 1 \mathrm{H}) ; 7.17(\mathrm{~s}, 2 \mathrm{H}) ; 8.26(\mathrm{~d}, J=3.68 \mathrm{~Hz}, 1 \mathrm{H}) .{ }^{13} \mathrm{C}-\mathrm{NMR}\left(100 \mathrm{MHz}, \mathrm{CDCl}_{3}\right): \delta 157.78$, $155.99,153.18,151.22,145.17,136.98,131.89,124.12,123.62,105.89,34.42,30.26,24.38,23.55$. ESI-MS $\mathrm{m} / \mathrm{z}$ for $\mathrm{C}_{21} \mathrm{H}_{25} \mathrm{Cl}_{2} \mathrm{~N}_{3} \mathrm{O}_{2} \mathrm{~S}$ calcd. at 453.10 , found at $454.10[\mathrm{M}+\mathrm{H}]^{+}$. Anal. calcd. for $\mathrm{C}_{21} \mathrm{H}_{25} \mathrm{Cl}_{2} \mathrm{~N}_{3} \mathrm{O}_{2} \mathrm{~S}: \mathrm{C}$, $55.51 ; \mathrm{H}, 5.55 ; \mathrm{N}, 9.25$. Found: C, 55.49; H, 5.54; N, 9.24.

2,4-dichloro-5-benzyl-5H-pyrrolo[3,2-d]pyrimidine (9). ${ }^{1} \mathrm{H}-\mathrm{NMR}\left(400 \mathrm{MHz}, \mathrm{CDCl}_{3}\right)(\mathrm{ppm}) \delta: 5.67(\mathrm{~s}, 2 \mathrm{H})$; $6.71(\mathrm{~d}, J=3.2 \mathrm{~Hz}, 1 \mathrm{H}) ; 7.05(\mathrm{~d}, J=6.44 \mathrm{~Hz}, 2 \mathrm{H}) ; 7.34(\mathrm{~m}, 3 \mathrm{H}) ; 7.53(\mathrm{~d}, J=3.2 \mathrm{~Hz}, 1 \mathrm{H}) .{ }^{13} \mathrm{C}-\mathrm{NMR}$ $\left(100 \mathrm{MHz}, \mathrm{CDCl}_{3}\right): 154.4,4,150.61,143.16,138.92,136.36,129.25,128.48,126.63,123.15,103.00,52.41$. ESI-MS $m / z$ for $\mathrm{C}_{13} \mathrm{H}_{9} \mathrm{Cl}_{2} \mathrm{~N}_{3}$ calcd. at 277.02 , found at $278.03[\mathrm{M}+\mathrm{H}]^{+}$. Anal. calcd. for $\mathrm{C}_{13} \mathrm{H}_{9} \mathrm{Cl}_{2} \mathrm{~N}_{3}$ : C, 56.14; H, 3.26; N, 15.11. Found: C, 56.11; H, 3.26; N, 15.10.

2,4-dichloro-5-(2,4-dichlorobenzyl)-5H-pyrrolo[3,2-d]pyrimidine (10). ${ }^{1} \mathrm{H}-\mathrm{NMR}\left(400 \mathrm{MHz}, \mathrm{CDCl}_{3}\right)$ (ppm) $\delta: 5.72(\mathrm{~s}, 2 \mathrm{H}) ; 6.42(\mathrm{~d}, J=8.68 \mathrm{~Hz}, 1 \mathrm{H}) ; 6.75(\mathrm{~d}, J=3.24 \mathrm{~Hz}, 1 \mathrm{H}) ; 7.15(\mathrm{~d}, J=8.28 \mathrm{~Hz}, 1 \mathrm{H}) ; 7.46(\mathrm{~d}$, $J=2.28 \mathrm{~Hz}, 1 \mathrm{H}) ; 7.51(\mathrm{~d} J=3.20 \mathrm{~Hz}, 1 \mathrm{H}) .{ }^{13} \mathrm{C}-\mathrm{NMR}\left(100 \mathrm{MHz}, \mathrm{DMSO}-d_{6}\right): \delta 154.39,149.55,142.77$, $142.23,135.14,133.24,132.01,129.52,128.13,122.50,103.03,49.67$. ESI-MS $m / z$ for $\mathrm{C}_{13} \mathrm{H}_{7} \mathrm{Cl}_{4} \mathrm{~N}_{3}$ calcd. at 344.94, found at $345.95[\mathrm{M}+\mathrm{H}]^{+}$. Anal. calcd. for $\mathrm{C}_{13} \mathrm{H}_{7} \mathrm{Cl}_{4} \mathrm{~N}_{3}: \mathrm{C}, 45.00 ; \mathrm{H}, 2.03 ; \mathrm{N}, 12.11$. Found: $\mathrm{C}$, 44.96; H, 2.03; N, 12.09.

2,4-dichloro-5-(4-methoxybenzyl)-5H-pyrrolo[3,2-d]pyrimidine (11). ${ }^{1} \mathrm{H}-\mathrm{NMR}\left(400 \mathrm{MHz}, \mathrm{CDCl}_{3}\right)$ (ppm) $\delta$ : $3.78(\mathrm{t}, J=7.36 \mathrm{~Hz}, 3 \mathrm{H}) ; 5.60(\mathrm{~d}, J=3.68 \mathrm{~Hz}, 2 \mathrm{H}) ; 6.67(\mathrm{~s}, 1 \mathrm{H}) ; 6.86(\mathrm{q}, J=4.12 \mathrm{~Hz}, 2 \mathrm{H}) ; 7.03(\mathrm{t}, J=3.68 \mathrm{~Hz}$, 2H); $7.50(\mathrm{~s}, 1 \mathrm{H}) .{ }^{13} \mathrm{C}-\mathrm{NMR}\left(100 \mathrm{MHz}\right.$, DMSO- $\left.d_{6}\right): \delta 159.48,155.10,149.01,142.96,141.49,141.00,130.06$, $128.35,123.01,114.97,102.07,55.61,51.20$. ESI-MS $m / z$ for $\mathrm{C}_{14} \mathrm{H}_{11} \mathrm{Cl}_{2} \mathrm{~N}_{3} \mathrm{O}$ calcd. at 307.03 , found at $307.93[\mathrm{M}+\mathrm{H}]^{+}$. Anal. calcd. for $\mathrm{C}_{14} \mathrm{H}_{11} \mathrm{C}_{12} \mathrm{~N}_{3} \mathrm{O}: \mathrm{C}, 54.57 ; \mathrm{H}, 3.60 ; \mathrm{N}, 13.64$. Found: $\mathrm{C}, 54.54 ; \mathrm{H}, 3.60$; $\mathrm{N}, 13.63$.

1-(2,4-dichloro-5H-pyrrolo[3,2-d]pyrimidin-5-yl)ethan-1-one (12). ${ }^{1} \mathrm{H}-\mathrm{NMR}\left(400 \mathrm{MHz}, \mathrm{CDCl}_{3}\right)$ (ppm) $\delta$ : $2.73(\mathrm{~s}, 3 \mathrm{H}) ; 6.77(\mathrm{~d}, J=3.64 \mathrm{~Hz}, 1 \mathrm{H}) ; 7.92(\mathrm{~d}, J=4.12 \mathrm{~Hz}, 1 \mathrm{H}) .{ }^{13} \mathrm{C}-\mathrm{NMR}\left(100 \mathrm{MHz}\right.$, DMSO- $\left.d_{6}\right): \delta 168.26$, $158.29,152.17,145.87,140.28,123.01,107.93,24.18$. ESI-MS $m / z$ for $\mathrm{C}_{8} \mathrm{H}_{5} \mathrm{Cl}_{2} \mathrm{~N}_{3} \mathrm{O}$ calcd. at 228.98 , found at $229.54[\mathrm{M}+\mathrm{H}]^{+}$. Anal. calcd. for $\mathrm{C}_{8} \mathrm{H}_{5} \mathrm{Cl}_{2} \mathrm{~N}_{3} \mathrm{O}: \mathrm{C}, 41.77 ; \mathrm{H}, 12.19 ; \mathrm{N}, 18.27$. Found: $\mathrm{C}, 41.75 ; \mathrm{H}, 2.19$; $\mathrm{N}, 18.25$.

1-(2,4-dichloro-5H-pyrrolo[3,2-d]pyrimidin-5-yl)-2-methylpropan-1-one (13). ${ }^{1} \mathrm{H}-\mathrm{NMR}\left(400 \mathrm{MHz}, \mathrm{CDCl}_{3}\right)$ (ppm) $\delta: 1.37(\mathrm{~d}, J=6.84 \mathrm{~Hz}, 6 \mathrm{H}) ; 3.33$ (septet, $J=6.88 \mathrm{~Hz}, 1 \mathrm{H}) ; 6.77(\mathrm{~d}, J=3.68 \mathrm{~Hz}, 1 \mathrm{H}) ; 7.92(\mathrm{~d}$, $J=3.64 \mathrm{~Hz}, 1 \mathrm{H}) .{ }^{13} \mathrm{C}-\mathrm{NMR}\left(100 \mathrm{MHz}\right.$, DMSO- $\left.d_{6}\right): 8174.60,158.78,152.44,146.37,138.82,124.21,106.45$, 34.17, 19.07. ESI-MS $m / z$ for $\mathrm{C}_{10} \mathrm{H}_{9} \mathrm{Cl}_{2} \mathrm{~N}=\mathrm{O}$ calcd. at 257.01 , found at $257.68[\mathrm{M}+\mathrm{H}]^{+}$. Anal. calcd. for $\mathrm{C}_{10} \mathrm{H}_{9} \mathrm{Cl}_{2} \mathrm{~N}_{3} \mathrm{O}: \mathrm{C}, 46.54 ; \mathrm{H}, 3.51 ; \mathrm{N}, 16.28$. Found: $\mathrm{C}, 46.51 ; \mathrm{H}, 3.51 ; \mathrm{N}, 16.27$.

2,4-dichloro-N,N-diphenyl-5H-pyrrolo[3,2-d]pyrimidine-5-carboxamide (14). ${ }^{1} \mathrm{H}-\mathrm{NMR}\left(400 \mathrm{MHz}\right.$, DMSO-d $\left.\mathrm{d}_{6}\right)$ (ppm) $\delta: 6.76(\mathrm{~d}, J=3.20 \mathrm{~Hz}, 1 \mathrm{H}) ; 7.23-7.34(\mathrm{~m}, 10 \mathrm{H}) ; 8.37(\mathrm{~d}, J=3.20 \mathrm{~Hz}, 1 \mathrm{H}) .{ }^{13} \mathrm{C}-\mathrm{NMR}(100 \mathrm{MHz}$, DMSO- $\left.d_{6}\right): \delta 155.30,151.12,149.65,144.15,141.73,139.55,130.09,123.10,104.63$. ESI-MS $\mathrm{m} / \mathrm{z}$ for $\mathrm{C}_{19} \mathrm{H}_{12} \mathrm{Cl}_{2} \mathrm{~N}_{4} \mathrm{O}$ calcd. at 382.04, found at $383.04[\mathrm{M}+\mathrm{H}]^{+}$. Anal. calcd. for $\mathrm{C}_{19} \mathrm{H}_{12} \mathrm{Cl}_{2} \mathrm{~N}_{4} \mathrm{O}: \mathrm{C}, 59.55 ; \mathrm{H}$, 3.16; N, 14.62. Found: C, 59.53; H, 3.16; N, 14.61 .

2-(2,4-dichloro-5H-pyrrolo[3,2-d]pyrimidin-5-yl)ethan-1-ol (15). ${ }^{1} \mathrm{H}-\mathrm{NMR}(400 \mathrm{MHz}$, DMSO-d 6 ) (ppm) $\delta$ : $3.70(\mathrm{~d}, J=5.52 \mathrm{~Hz}, 2 \mathrm{H}) ; 4.50(\mathrm{t}, J=5.48 \mathrm{~Hz}, 2 \mathrm{H}) ; 6.68(\mathrm{~d}, J=3.24 \mathrm{~Hz}, 1 \mathrm{H}) ; 8.05(\mathrm{~d}, J=3.20 \mathrm{~Hz}, 1 \mathrm{H}) ; 8.08$ $(\mathrm{s}, 1 \mathrm{H}) .{ }^{13} \mathrm{C}-\mathrm{NMR}\left(100 \mathrm{MHz}\right.$, DMSO- $\left.d_{6}\right)$ : $\delta 153.40,142.99,137.59,124.25,102.56,101.54,61.40,51.47$. ESI-MS $m / z$ for $\mathrm{C}_{8} \mathrm{H}_{7} \mathrm{Cl}_{2} \mathrm{~N}_{3} \mathrm{O}$ calcd. at 231.00 , found at $231.93[\mathrm{M}+\mathrm{H}]^{+}$ 
Supplementary Materials: The following are available online, Figure S1: Complete NCI-60 Mean Growth Charts, Figure S2: ${ }^{1} \mathrm{H}-\mathrm{NMR}$ of Compounds 6-15, Figure S3: ${ }^{13} \mathrm{C}-\mathrm{NMR}$ of Compounds 6-15.

Author Contributions: K.L.S.-R. and B.M.C. designed the synthesis of the experimental compounds, analyzed the NCI and COMPARE data, and prepared the manuscript. N.M.R. assisted in the synthesis of the experimental compounds. N.C.L. and G.M.W. conducted the MTT assays and prepared the resulting biological data. All authors edited and contributed to drafts of the manuscript.

Acknowledgments: The authors thank the National Institutes of Health and NIGMS for financial support through the Chemistry-Biology Interface Program (T32 GM066706, K.L.S.-R. and B.M.C.). N.C.L. was supported by the Nathan Schnaper Intern Program funded in part through NCI grant R25CA186872 to Bret A. Hassel.

Conflicts of Interest: The authors declare no conflict of interest.

\section{References}

1. Stefan, K.; Schmitt, S.M.; Wiese, M. 9-Deazapurines as Broad-Spectrum Inhibitors of the ABC Transport Proteins P-Glycoprotein, Multidrug Resistance-Associated Protein 1, and Breast Cancer Resistance Protein. J. Med. Chem. 2017, 60, 8758-8780. [CrossRef] [PubMed]

2. de Coen, L.M.; Heugebaert, T.S.; García, D.; Stevens, C.V. Synthetic Entries to and Biological Activity of Pyrrolopyrimidines. Chem. Rev. 2016, 116, 80-139. [CrossRef] [PubMed]

3. Gangjee, A.; Li, W.; Yang, J.; Kisliuk, R.L. Design, synthesis, and biological evaluation of classical and nonclassical 2-amino-4-oxo-5-substituted-6-methylpyrrolo[3,2-d]pyrimidines as dual thymidylate synthase and dihydrofolate reductase inhibitors. J. Med. Chem. 2008, 51, 68-76. [CrossRef] [PubMed]

4. Shih, H.; Cottam, H.B.; Carson, D.A. Facile synthesis of 9-substituted 9-deazapurines as potential purine nucleoside phosphorylase inhibitors. Chem. Pharm. Bull. 2002, 50, 364-367. [CrossRef] [PubMed]

5. Sircar, J.C.; Kostlan, C.R.; Pinter, G.W.; Suto, M.J.; Bobovski, T.P.; Capiris, T.; Schwender, C.F.; Dong, M.K.; Scott, M.E.; Bennett, M.K.; et al. 8-Amino-9-substituted guanines: Potent purine nucleoside phosphorylase (PNP) inhibitors. Agents Actions 1987, 21, 253-256. [CrossRef] [PubMed]

6. Sircar, J.C.; Kostlan, C.R.; Gilbertsen, R.B.; Bennett, M.K.; Dong, M.K.; Cetenko, W.J. Inhibitors of human purine nucleoside phosphorylase. Synthesis of pyrrolo[3,2-d]pyrimidines, a new class of purine nucleoside phosphorylase inhibitors as potentially T-cell selective immunosuppressive agents. Description of 2,6-diamino-3,5-dihydro-7-(3-thienylmethyl)-4H-pyrrolo[3,2-d]pyrimidin-4-one. J. Med. Chem. 1992, 35, 1605-1609. [PubMed]

7. Montgomery, J.A.; Niwas, S.; Rose, J.D.; Secrist, J.A., III; Babu, Y.S.; Bugg, C.E.; Erion, M.D.; Guida, W.C.; Ealick, S.E. Structure-based design of inhibitors of purine nucleoside phosphorylase. 1. 9-(arylmethyl) derivatives of 9-deazaguanine. J. Med. Chem. 1993, 36, 55-69. [CrossRef]

8. Secrist, J.A., III; Niwas, S.; Rose, J.D.; Babu, Y.S.; Bugg, C.E.; Erion, M.D.; Guida, W.C.; Ealick, S.E.; Montgomery, J.A. Structure-based design of inhibitors of purine nucleoside phosphorylase. 2. 9-Alicyclic and 9-heteroalicyclic derivatives of 9-deazaguanine. J. Med. Chem. 1993, 36, 1847-1854. [CrossRef]

9. Erion, M.D.; Niwas, S.; Rose, J.D.; Ananthan, S.; Allen, M.; Secrist, J.A., III; Babu, Y.S.; Bugg, C.E.; Guida, W.C. Structure-based design of inhibitors of purine nucleoside phosphorylase. 3. 9-Arylmethyl derivatives of 9-deazaguanine substituted on the methylene group. J. Med. Chem. 1993, 36, 3771-3783. [CrossRef]

10. Baraldi, P.G.; Romagnoli, R.; Saponaro, G.; Tabrizi, M.A.; Baraldi, S.; Pedretti, P.; Fusi, C.; Nassini, R.; Materazzi, S.; Geppetti, P.; et al. 7-Substituted-pyrrolo[3,2-d]pyrimidine-2,4-dione derivatives as antagonists of the transient receptor potential ankyrin 1 (TRPA1) channel: A promising approach for treating pain and inflammation. Bioorg. Med. Chem. 2012, 20, 1690-1698. [CrossRef]

11. Ishikawa, T.; Seto, M.; Banno, H.; Kawakita, Y.; Oorui, M.; Taniguchi, T.; Ohta, Y.; Tamura, T.; Nakayama, A.; Miki, H.; et al. Design and Synthesis of Novel Human Epidermal Growth Factor Receptor 2 (HER2)/Epidermal Growth Factor Receptor (EGFR) Dual Inhibitors Bearing a Pyrrolo 3,2-d pyrimidine Scaffold. J. Med. Chem. 2011, 54, 8030-8050. [CrossRef] [PubMed]

12. Kawakita, Y.; Miwa, K.; Seto, M.; Banno, H.; Ohta, Y.; Tamura, T.; Yusa, T.; Miki, H.; Kamiguchi, H.; Ikeda, Y.; et al. Design and synthesis of pyrrolo[3,2-d]pyrimidine HER2/EGFR dual inhibitors: Improvement of the physicochemical and pharmacokinetic profiles for potent in vivo anti-tumor efficacy. Bioorg. Med. Chem. 2012, 20, 6171-6180. [CrossRef] [PubMed] 
13. Sogabe, S.; Kawakita, Y.; Igaki, S.; Iwata, H.; Miki, H.; Cary, D.R.; Takagi, T.; Takagi, S.; Ohta, Y.; Ishikawa, T. Structure-Based Approach for the Discovery of Pyrrolo[3,2-d]pyrimidine-Based EGFR T790M/L858R Mutant Inhibitors. ACS Med. Chem. Lett. 2013, 4, 201-205. [CrossRef] [PubMed]

14. Gangjee, A.; Pavana, R.K.; Li, W.; Hamel, E.; Westbrook, C.; Mooberry, S.L. Novel water-soluble substituted pyrrolo[3,2- $d$ ]pyrimidines: design, synthesis, and biological evaluation as antitubulin antitumor agents. Pharm. Res. 2012, 29, 3033-3039. [CrossRef] [PubMed]

15. Cawrse, B.M.; Lapidus, R.S.; Cooper, B.; Choi, E.Y.; Seley-Radtke, K.L. Anticancer Properties of Halogenated Pyrrolo[3,2-d]pyrimidines with Decreased Toxicity via N5 Substitution. ChemMedChem 2018, 13, 178-185. [CrossRef] [PubMed]

16. Temburnikar, K.W.; Ross, C.R.; Wilson, G.M.; Balzarini, J.; Cawrse, B.M.; Seley-Radtke, K.L. Antiproliferative activities of halogenated pyrrolo[3,2-d]pyrimidines. Bioorg. Med. Chem 2015, 23, 4354-4363. [CrossRef] [PubMed]

17. Schmitt, S.M.; Stefan, K.; Wiese, M. Pyrrolopyrimidine derivatives and purine analogs as novel activators of Multidrug Resistance-associated Protein 1 (MRP1, ABCC1). Biochim. Biophys. Acta 2017, 1859, 69-79. [CrossRef] [PubMed]

18. Wang, S.M.; Folkes, A.; Chuckowree, I.; Cockcroft, X.; Sohal, S.; Miller, W.; Milton, J.; Wren, S.P.; Vicker, N.; Depledge, P.; et al. Studies on pyrrolopyrimidines as selective inhibitors of multidrug-resistance-associated protein in multidrug resistance. J. Med. Chem. 2004, 47, 1329-1338. [CrossRef]

19. Vaseghi, G.; Jafari, E.; Hassanzadeh, F.; Haghjooy-Javanmard, S.; Dana, N.; Rafieian-Kopaei, M. Cytotoxic Evaluation of Some Fused Pyridazino-and Pyrrolo-quinazolinones Derivatives on Melanoma and Prostate Cell Lines. Adv. Biomed. Res. 2017, 6, 76.

20. Lee, B.D.; Li, Z.; French, K.J.; Zhuang, Y.; Xia, Z.; Smith, C.D. Synthesis and evaluation of dihydropyrroloquinolines that selectively antagonize P-glycoprotein. J. Med. Chem. 2004, 47, 1413-1422. [CrossRef]

21. Tawari, N.R.; Bag, S.; Degani, M.S. Pharmacophore mapping of a series of pyrrolopyrimidines, indolopyrimidines and their congeners as multidrug-resistance-associated protein (MRP1) modulators. J. Mol. Model. 2008, 14, 911-921. [CrossRef] [PubMed]

22. Schmitt, S.M.; Stefan, K.; Wiese, M. Pyrrolopyrimidine Derivatives as Novel Inhibitors of Multidrug Resistance-Associated Protein 1 (MRP1, ABCC1). J. Med. Chem. 2016, 59, 3018-3033. [CrossRef] [PubMed]

23. Zeng, S.; Xie, H.; Zeng, L.L.; Lu, X.; Zhao, X.; Zhang, G.C.; Tu, Z.C.; Xu, H.J.; Yang, L.; Zhang, X.Q.; et al. Discovery of potent dipeptidyl peptidase IV inhibitors through pharmacophore hybridization and hit-to-lead optimization. Bioorg. Med. Chem. 2013, 21, 1749-1755. [CrossRef] [PubMed]

24. Xie, H.; Zeng, L.; Zeng, S.; Lu, X.; Zhang, G.; Zhao, X.; Cheng, N.; Tu, Z.; Li, Z.; Xu, H.; et al. Novel pyrrolopyrimidine analogues as potent dipeptidyl peptidase IV inhibitors based on pharmacokinetic property-driven optimization. Eur. J. Med. Chem. 2012, 52, 205-212. [CrossRef] [PubMed]

25. Temburnikar, K.W.; Zimmermann, S.C.; Kim, N.T.; Ross, C.R.; Gelbmann, C.; Salomon, C.E.; Wilson, G.M.; Balzarini, J.; Seley-Radtke, K.L. Antiproliferative activities of halogenated thieno[3,2-d]pyrimidines. Bioorg. Med. Chem. 2014, 22, 2113-2122. [CrossRef] [PubMed]

26. Radtke, K.L.; Temburnikar, K. Thieno-and Pyrrolopyrimidine Analogues as Anticancer Agents and Methods of Use Thereof. U.S. Patent 9,434,742 B1, 6 September 2016 and U.S. Patent 9,434,742 B2, 20 February 2018.

27. Foley, G.E.; Lazarus, H.; Farber, S.; Uzman, B.G.; Boone, B.A.; McCarthy, R.E. Continuous Culture of Human Lymphoblasts from Peripheral Blood of a Child with Acute Leukemia. Cancer 1965, 18, 522-529. [CrossRef]

28. Ntie-Kang, F. An in silico evaluation of the ADMET profile of the StreptomeDB database. Springerplus 2013, 2, 353. [CrossRef]

29. Shoemaker, R.H.; Monks, A.; Alley, M.C.; Scudiero, D.A.; Fine, D.L.; McLemore, T.L.; Abbott, B.J.; Paull, K.D.; Mayo, J.G.; Boyd, M.R. Development of human tumor cell line panels for use in disease-oriented drug screening. Prog. Clin. Biol. Res. 1988, 276, 265-286.

30. Shoemaker, R.H. The NCI60 human tumour cell line anticancer drug screen. Nat. Rev. Cancer 2006, 6, 813-823. [CrossRef]

31. Holbeck, S.L.; Collins, J.M.; Doroshow, J.H. Analysis of Food and Drug Administration-approved anticancer agents in the NCI60 panel of human tumor cell lines. Mol. Cancer Ther. 2010, 9, 1451-1460. [CrossRef]

32. Paull, K.D.; Hamel, E.; Malspeis, L. COMPARE Analysis. Available online: https://dtp.cancer.gov/databases_ tools/compare.htm (accessed on 3 February 2019). 
33. Paull, K.D.; Shoemaker, R.H.; Hodes, L.; Monks, A.; Scudiero, D.A.; Rubinstein, L.; Plowman, J.; Boyd, M.R. Display and analysis of patterns of differential activity of drugs against human tumor cell lines: development of mean graph and COMPARE algorithm. J. Natl. Cancer Inst. 1989, 81, 1088-1092. [CrossRef] [PubMed]

34. Zaharevitz, D.W.; Holbeck, S.L.; Bowerman, C.; Svetlik, P.A. COMPARE: A web accessible tool for investigating mechanisms of cell growth inhibition. J. Mol. Graph. Model. 2002, 20, 297-303. [CrossRef]

35. Sausville, E.A.; Johnson, J.I. Molecules for the millennium: how will they look? New drug discovery year 2000. Br. J. Cancer 2000, 83, 1401-1404. [CrossRef] [PubMed]

36. Doroshow, J.H.; Juhasz, A.; Ge, Y.; Holbeck, S.; Lu, J.; Antony, S.; Wu, Y.; Jiang, G.; Roy, K. Antiproliferative mechanisms of action of the flavin dehydrogenase inhibitors diphenylene iodonium and di-2-thienyliodonium based on molecular profiling of the NCI-60 human tumor cell panel. Biochem. Pharmacol. 2012, 83, 1195-1207. [CrossRef] [PubMed]

37. Schober, P.; Boer, C.; Schwarte, L.A. Correlation Coefficients: Appropriate Use and Interpretation. Anesth. Analg. 2018, 126, 1763-1768. [CrossRef] [PubMed]

38. Monks, A.; Scudiero, D.A.; Johnson, G.S.; Paull, K.D.; Sausville, E.A. The NCI anti-cancer drug screen: A smart screen to identify effectors of novel targets. Anticancer Drug Des. 1997, 12, 533-541.

39. Neben-Wittich, M.A.; Atherton, P.J.; Schwartz, D.J.; Sloan, J.A.; Griffin, P.C.; Deming, R.L.; Anders, J.C.; Loprinzi, C.L.; Burger, K.N.; Martenson, J.A.; et al. Comparison of provider-assessed and patient-reported outcome measures of acute skin toxicity during a Phase III trial of mometasone cream versus placebo during breast radiotherapy: the North Central Cancer Treatment Group (N06C4). Int. J. Radiat. Oncol. Biol. Phys. 2011, 81, 397-402. [CrossRef] [PubMed]

40. Murphy, E.J.; Neuberg, D.S.; Rassenti, L.Z.; Hayes, G.; Redd, R.; Emson, C.; Li, K.; Brown, J.R.; Wierda, W.G.; Turner, S.; et al. Leukemia-cell proliferation and disease progression in patients with early stage chronic lymphocytic leukemia. Leukemia 2017, 31, 1348-1354. [CrossRef]

41. Landau, D.A.; Carter, S.L.; Getz, G.; Wu, C.J. Clonal evolution in hematological malignancies and therapeutic implications. Leukemia 2014, 28, 34-43. [CrossRef]

42. Civini, S.; Jin, P.; Ren, J.; Sabatino, M.; Castiello, L.; Jin, J.; Wang, H.; Zhao, Y.; Marincola, F.; Stroncek, D. Leukemia cells induce changes in human bone marrow stromal cells. J. Transl. Med. 2013, 11, 298. [CrossRef]

43. Prada-Arismendy, J.; Arroyave, J.C.; Röthlisberger, S. Molecular biomarkers in acute myeloid leukemia. Blood Rev. 2017, 31, 63-76. [CrossRef] [PubMed]

44. Liu, K.C.; Lin, Y.J.; Hsiao, Y.T.; Lin, M.L.; Yang, J.L.; Huang, Y.P.; Chu, Y.L.; Chung, J.G. Tetrandrine Induces Apoptosis in Human Nasopharyngeal Carcinoma NPC-TW 039 Cells by Endoplasmic Reticulum Stress and Ca. Anticancer Res. 2017, 37, 6107-6118. [PubMed]

45. Patel, S.R.; Kvols, L.K.; Rubin, J.; O’Connell, M.J.; Edmonson, J.H.; Ames, M.M.; Kovach, J.S. Phase I-II study of pibenzimol hydrochloride (NSC 322921) in advanced pancreatic carcinoma. Investig. New Drugs 1991, 9 , 53-57. [CrossRef]

46. Ferguson, L.R.; Denny, W.A. Microbial mutagenic effects of the DNA minor groove binder pibenzimol (Hoechst 33258) and a series of mustard analogues. Mutat. Res. 1995, 329, 19-27. [CrossRef]

47. Dubicki, H.; Zielinski, F.; Starks, F.r.W. Synthesis of 5-[(2-Fluoroethyl) (2-chloroethyl)amino]-6-methyl-uracil (Fluorodopan). J. Pharm. Sci. 1964, 53, 1422-1423. [CrossRef] [PubMed]

48. Esma, F.; Salvini, M.; Troia, R.; Boccadoro, M.; Larocca, A.; Pautasso, C. Melphalan hydrochloride for the treatment of multiple myeloma. Expert Opin. Pharmacother. 2017, 18, 1127-1136. [CrossRef] [PubMed]

49. Roux, A.; Peeters, S.; Zanello, M.; Bou Nassif, R.; Abi Lahoud, G.; Dezamis, E.; Parraga, E.; Lechapt-Zalcmann, E.; Dhermain, F.; Dumont, S.; et al. Extent of resection and Carmustine wafer implantation safely improve survival in patients with a newly diagnosed glioblastoma: a single center experience of the current practice. J. Neurooncol. 2017, 135, 83-92. [CrossRef] [PubMed]

50. Danovich, D.; Apeloig, Y.; Shaik, S. A reliable and inexpensive method for calculating ionization potentials and electron affinities of radicals and molecules. J. Chem. Soc. Perkin Trans. 1993, 2, 321-330. [CrossRef]

51. COMPARE Analysis. Available online: https://dtp.cancer.gov/databases_tools/compare.htm (accessed on 10 March 2018).

52. Ponticello, G.S.; Baldwin, J.J. Useful synthesis of 4-substituted indoles. J. Org. Chem. 1979, 44, $4003-4005$. [CrossRef] 
53. Hirota, K.; Abe, Y.; Asao, T.; Senda, S.; Kitade, Y.; Maki, Y. Ring transformation of pyrimidines to pyridines. Synthesis of 4-alkylaminopyridin-2-ones by alkaline hydrolysis of 6-(2-dimethylaminovinyl)uracils. J. Heterocycl. Chem. 1988, 25, 985-990. [CrossRef]

54. Girgis, N.S.; Cottam, H.B.; Larson, S.B.; Robins, R.K. 9-deazapurine nucleosides. The synthesis of certain $N$-5-2' -deoxy- $\beta$-D-erythropentofuranosyl and $N$-5- $\beta$-D-arabinofuranosylpyrrolo[3,2- $d$ ] pyrimidines. J. Heterocycl. Chem. 1987, 24, 821-827. [CrossRef]

Sample Availability: Samples of the compounds 5-15 are available from the authors.

(C) 2019 by the authors. Licensee MDPI, Basel, Switzerland. This article is an open access article distributed under the terms and conditions of the Creative Commons Attribution (CC BY) license (http://creativecommons.org/licenses/by/4.0/). 